\title{
BEATTY, J.F., AND THE LAW OF MANSLAUGHTER
}

\author{
LARRY C. WILSON*
}

In this article, the author argues that the recent Supreme Court of Canada decisions in R. v. Beatty and R. v. J.F. have clarified several of the issues that have plagued the increasingly complicated offence of manslaughter. In particular, the decisions address the redundancy among the many manslaughter provisions in the Criminal Code, the need to define a clear separation between actus reus and mens rea, and the need to establish distinct categories of objective fault for different types of manslaughter offences. The author examines the legal background of these decisions as well as the current state of the law. He concludes by identifying emerging issues relating to the offence of manslaughter, arguing that the law remains convoluted and in need of urgent reform despite the progress made in the Beatty and J.F. decisions.
Dans cet article, l'auteur fait valoir que les récentes décisions de la Cour suprême du Canada, notamment R. c. Beatty et R. c. J.F., ont clarifié plusieurs questions qui tourmentent l'homicide involontaire coupable, infraction de plus en plus compliquée. Les décisions abordent tout spécialement la redondance des nombreuses dispositions relatives à l'homicide involontaire coupable du Code criminel, le besoin de préciser une séparation claire entre actus reus et mens rea, et le besoin d'établir des catégories distinctes de faute objective pour différents types d'homicides involontaires coupables. L'auteur examine le contexte juridique de ces décisions ainsi que l'état actuel de la loi. Il termine en identifiant les enjeux émergents relatifs à ce crime en faisant valoir que la loi demeure alambiquée et qu'une réforme urgente s'impose malgré les progrès faits dans Beatty et J.F.

\section{TABLE OF CONTENTS}

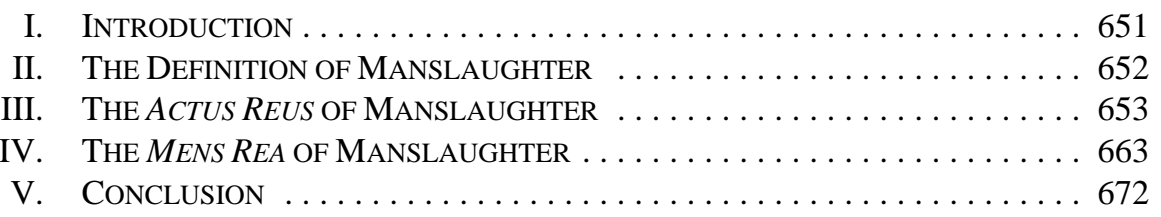

\section{INTRODUCTION}

Two recent decisions of the Supreme Court of Canada have resolved a number of important issues regarding the offence of manslaughter. In Beatty, ${ }^{1}$ the Court examined the distinction between civil and penal negligence in the context of a charge of dangerous driving causing death. The majority of the Court, relying on its earlier decision in Hundal, ${ }^{2}$ determined that the fault element for this offence should be based on a modified objective test, namely that the conduct amounted to a "marked departure from the standard of care that a reasonable person would observe in ... the circumstances" of the accused. ${ }^{3}$ In this case a "momentary lapse of attention," while amounting to civil negligence, was insufficient to support a finding of a marked departure from the standard of care of a prudent driver. ${ }^{4}$ In J.F., ${ }^{5}$ the focus was on different levels of fault for objective crimes within the Criminal Code. ${ }^{6}$ The accused was charged with manslaughter by criminal negligence and with manslaughter by failing to provide the necessaries of life in the death of his son. A jury

Professor, Faculty of Law, University of Windsor.

R. v. Beatty, 2008 SCC 5, [2008] 1 S.C.R. 49 [Beatty].

R. v. Hundal, [1993] 1 S.C.R. 867 [Hundal].

Beatty, supra note 1 at para. 36 [emphasis in original].

Ibid. at para. 51 .

R. v. J.F., 2008 SCC 60, [2008] 3 S.C.R. 215 [J.F.].

R.S.C. 1985 , c. C-46. 
convicted the accused on the first count but acquitted on the second. The Court held that these verdicts were inconsistent in that the accused had been convicted and acquitted of what amounted to essentially the same offence. In their analysis, the majority indicated that the fault element for manslaughter by failure to provide necessaries was a "marked departure," while the fault element for manslaughter by criminal negligence, described as a "more serious" offence, was a "marked and substantial" departure. ${ }^{7}$ Thus, the verdicts were incomprehensible as they signified "that a lesser degree of fault was not established, while a greater degree of fault was proven beyond a reasonable doubt.”8

In this article I will examine the background leading to these important decisions, provide a synopsis of the current state of the law of manslaughter in Canada, and identify some of the emerging issues that have yet to be resolved. I will also use this opportunity to join the chorus of those who argue that there is an urgent need for comprehensive reform of Canadian criminal law, particularly the law of homicide.

\section{The Definition OF MANSLAUghter}

Our Criminal Code provides that a person commits homicide when, "directly or indirectly, by any means, he causes the death of a human being." ${ }^{\prime 9}$ Of course this does not mean that there is criminal responsibility every time someone causes the death of another. Homicides are classified as "culpable or not culpable" and a "[h]omicide that is not culpable is not an offence." 10 There will only be criminal responsibility for culpable homicides. Many deaths, although caused by another, may be the result of accident or occur in circumstances where there is an absence of fault or the operation of an excuse or justification such as self-defence. The legislation further provides that "[c]ulpable homicide is murder or manslaughter or infanticide." 11 Thus, where an accused has "directly or indirectly ... cause[d] the death of a human being," and that death is found to be culpable, the offence must be "murder or manslaughter or infanticide." 12 If a culpable homicide does not fit the definition of murder or infanticide, it must be manslaughter: the Criminal Code specifically provides that "[c]ulpable homicide that is not murder or infanticide is manslaughter." "13

Murder is distinguished from manslaughter primarily on the basis of the required fault element: murder requires subjective foresight of death, while manslaughter does not. ${ }^{14}$ On a charge of murder, the Crown must prove that the accused intended to cause death, or intended to "cause ... bodily harm that he [knew was] likely to cause ... death." 15 Infanticide also requires proof of subjective fault, and is further distinguished from manslaughter by the precise requirements of the actus reus. ${ }^{16}$ On a charge of infanticide, the accused must be female and the victim must be a "newly-born child."17

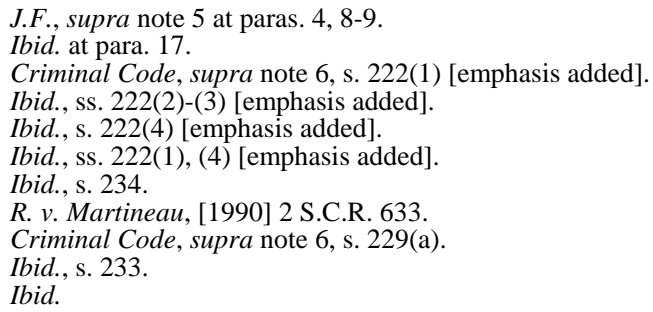


Section 222(5) of the Criminal Code states that a homicide will be a culpable homicide when an accused has caused "the death of a human being, (a) by means of an unlawful act; (b) by criminal negligence; (c) ... by threats or fear of violence or by deception,” which causes the victim to bring about her own death; or “(d) by wilfully frightening [the victim], in the case of a child or sick person.”" 18 Thus, if an accused caused the death of a person through any of these alternate routes, and the conduct did not satisfy the actus reus or mens rea requirements of either murder or infanticide, in the absence of any other defences the conviction would be for manslaughter.

Section 222(5) is found in the "Homicide" section of the Criminal Code. However, there are a large number of other offences not found in that section that hold an accused criminally responsible for causing the death of another human being. Arguably, these offences also fit the definition of manslaughter: they are homicides (defined as "directly or indirectly, by any means, ... caus[ing] the death of a human being”), they are culpable, and they are neither murder nor infanticide. ${ }^{19}$ In this discussion I will include these offences in the definition of manslaughter. The best known example is the offence of causing death by criminal negligence (s. 220). ${ }^{20}$ The list also includes offences such as dangerous driving causing death (s. 294(4)) and impaired driving causing death (s. 255(3)). ${ }^{21}$ Some lesser known offences that fit the definition include causing death through a breach of the duty to properly handle explosives (s. 80), neglecting to obtain assistance in childbirth leading to death (s. 242), using traps causing death (s. 247(5)), causing death while operating a motor vehicle in a dangerous manner and fleeing a police officer (s. 249.1(3)), causing death by criminal negligence (street racing) (s. 249.2), dangerous operation of a motor vehicle causing death while street racing (s. 249.4(4)), and failing to guard an opening in ice or excavation on land causing death (s. 263). ${ }^{22}$ In addition, a person can be convicted of manslaughter as a party (s. 21), and there is a specific offence of counselling or aiding suicide (s. 241), which would appear to be included in the phrase that defines manslaughter: "directly or indirectly, by any means ... caus[ing] the death of a human being." ${ }^{23}$ Where an accused is initially charged with murder, the operation of certain defences (intoxication, provocation, and mental disorder short of insanity) may entitle the accused to a conviction for manslaughter. ${ }^{24}$ Finally, an organization such as a corporation can be convicted of manslaughter. ${ }^{25}$

\section{The ACtus ReUS Of MANSLAUghter}

Manslaughter is often described as being either "voluntary" or "involuntary," the distinction being that "voluntary" manslaughter involves situations where conduct that would otherwise constitute murder is reduced to manslaughter as a result of a mitigating

Ibid., s. 222(5). Section 228 of the Criminal Code provides that it is not a "culpable homicide where [an accused] causes the death of a human being (a) by any influence on the mind alone, or (b) by any disorder or disease resulting from influence on the mind alone, [except] where a person causes the death of a child or sick person by willfully frightening him [or her]."

Ibid., s. 222.

Ibid., s. 220.

Ibid., ss. 294(4), 255(3).

Killing an unborn child "in the act of birth" does not fit the definition of homicide since the death is not caused to a human being (ibid., s. 238). The section specifically refers to "any child that has not become a human being" (ibid.).

Ibid., s. 222(1). If you counsel an offence you are a party to that offence (ibid., s. 22).

Ibid., s. 33.1 (intoxication), s. 232 (provocation), s. 16 (mental disorder); see also infra notes 153-58. Ibid., s. 22.1. 
circumstance, such as provocation, while “involuntary” manslaughter involves any situation where the fault element for murder cannot be established. ${ }^{26}$ The distinction is misleading since an essential component of the actus reus for all criminal offences, including manslaughter, is a voluntary act. ${ }^{27} \mathrm{~A}$ death, and a causal link between the voluntary act and the death, are also required:

The actus reus for most offences is defined in terms of the accused's conduct in certain circumstances. At the stage of determining liability based on an act, the consequences for the victim are thus normally irrelevant. Sometimes, however, especially in the case of offences against the person, certain consequences of an act may be part of the definition of the crime and may have to be proved beyond a reasonable doubt. The classic example is, of course, death in the case of all homicide offences.... The common law has also developed general principles to ensure that the act requirement be meaningful. Under present Canadian law, an act must, in addition to coming within the precise offence definition, be an act

1. of commission, or,

2. in certain cases only, of omission,

3. by a human being,

4. that is voluntary, and,

5. if consequences are part of the definition, have caused those consequences.

If any of these essentials are lacking, the accused must be acquitted. ${ }^{28}$

In addition to proof of the voluntary act, a causal link, and the consequence of death, the various types of manslaughter require proof of their own unique factual circumstances. ${ }^{29}$ As noted above, in some cases positive acts such as threats or the use of automobiles, explosives, or traps are required by the legislation. ${ }^{30}$ In other instances an omission will suffice, such as the failure to guard an ice hole. Some manslaughters require certain categories of victims, such as children. Parliament has not created different murder offences based on the manner of causing death or the identity of the victim. While these factors appropriately play an important role in sentencing, they do not form part of the definition of the offence of murder. ${ }^{31}$

The actus rea for unlawful act culpable homicide and criminal negligence causing death have generated a great deal of debate, but now appear to be settled. Unlawful act manslaughter, as its name implies, requires proof of an unlawful act. The actus reus of that

R. v. Worrall (2004), 19 C.R. (6th) 213 at paras. 5-7 (Ont. Sup. Ct. J.) [Worrall].

Glanville Williams, Textbook of Criminal Law, 2d ed. (London: Stevens \& Sons, 1983) at 258-59.

Don Stuart, Canadian Criminal Law: A Treatise, 5th ed. (Scarborough: Thomson Canada, 2007) at 8182 [Stuart, Canadian Criminal Law] [emphasis in original].

Consequences are a result of an act by the accused, while circumstances are "facts specified in law as conditions of the offence": see Williams, supra note 27 at 77, 115.

See Part II, above.

Criminal Code, supra note 6, s. 231 (providing that murder will be first degree murder where the murder is committed during the commission of certain offences - sexual assault and kidnapping, for example — or where the victim is a police officer or prison guard). 
unlawful act will form part of the actus reus for the manslaughter charge. The unlawful act, commonly called a predicate offence, can be any offence, federal or provincial, other than an offence of absolute liability. ${ }^{32}$

Until recently, there was considerable authority to the effect that the "marked departure" test was part of the actus reus. ${ }^{33}$ In both Beatty and J.F., the Supreme Court attempted to end the debate and held that negligence is properly viewed as a form of fault, not actus reus:

[J.F.] resolves the question of whether the element of departing from the standard of care is a conduct element (part of the actus reus) or a fault element (part of the mens rea). In Beatty, decided earlier this year, the court considered that very question in the context of the offence of dangerous driving causing death. The court was (nearly) unanimously of the view that to prove dangerous driving, the Crown had to prove a marked departure from the standard of care expected of the reasonable driver in the circumstances, but divided on the proper conceptualization of this element. The majority considered it a fault element; the minority considered it an aspect of the actus reus. ${ }^{34}$

What then is the actus reus for offences of criminal negligence? Professor David Tanovich correctly states that "the actus reus for criminal negligence offences should be defined by the statutory language, that is, proof that the accused has done something or failed to do something for which he had a legal duty that shows a wanton and reckless disregard for the lives or safety of others.” ${ }^{35}$ In future decisions, courts will face significant challenges trying to distinguish between conduct that satisfies one element of the offence but not the other, an actus reus of wanton and reckless disregard and a mens rea of marked and substantial departure. This may prove difficult if not impossible. However, even the strongest critics concede that the approach adopted by the majority in J.F. is unlikely to cause any injustice as the Crown will still be required to prove, beyond a reasonable doubt, both actus reus and mens rea. ${ }^{36}$

The definition of criminal negligence found in s. 219 of the Criminal Code is used both for the prosecution of the offence of criminal negligence causing death in s. 220 and for a charge of manslaughter based on s. 222(5)(b). Also, the penalty upon conviction for causing death by criminal negligence is identical to the penalty provided for a conviction for

R. v. DeSousa, [1992] 2 S.C.R. 944; R. v. Creighton, [1993] 3 S.C.R. 3 [Creighton].

See the decision of Wilson J. in R. v. Tutton, [1989] 1 S.C.R. 1392 [Tutton]. See also R. v. L. (J.) (2006), 206 O.A.C. 205 [L. (J.)]; R. v. T. (K.), 2005 MBCA 78, 195 Man. R. (2d) 89 [T. (K.)]; R. v. Willock (2006), 212 O.A.C. 82 [Willock].

H. Stewart, "F.(J.): The Continued Evolution of the Law of Penal Negligence” (2008) 60 C.R. (6th) 243 at 246.

David M. Tanovich, “The Implications of Beatty For Criminal Negligence” (2008) 54 C.R. (6th) 38 at 39.

Stewart, supra note 34 at 243, 249. In an earlier comment on the Beatty decision Professor Hamish Stewart outlined his preferred approach:

From the point of view of basic criminal law principles, a "marked departure" is best understood as an aspect of the accused's conduct; the fault element of penal negligence is then best understood as the requirement that a reasonable person in the accused's circumstances would have been aware of the risk created by the marked departure (the particular risk depending on the definition of the actus reus).

Hamish Stewart, “Beatty: Towards a Coherent Law of Penal Negligence” (2008) 54 C.R. (6th) 45 at $54-$ 55. 
manslaughter: liable to imprisonment for life. ${ }^{37}$ In Morrisey, ${ }^{38}$ Arbour J. noted that there is, in fact, no difference between causing death by criminal negligence and manslaughter by criminal negligence. She described the two offences as "totally interchangeable."39 Accordingly, where both offences are charged there will generally only be a conviction for one. The decision of $R$. v. Hariczuk ${ }^{40}$ provides an excellent example. The deceased child drank methadone-laced orange juice that had been left in a refrigerator by the accused. The accused was charged with manslaughter, criminal negligence causing death, and failure to provide the necessaries of life to a child. The Court found the accused guilty of manslaughter, noting that the Crown had established both unlawful act manslaughter and criminal negligence manslaughter. The charges of criminal negligence causing death and failing to provide the necessaries of life were stayed. There are a number of other such decisions. $^{41}$

On the other hand, there have been cases where an accused has been charged with and convicted of multiple "causing death" offences in circumstances where, arguably, only one charge and/or conviction was necessary. Recent examples include R. v. Hall ${ }^{42}$ and $R$. v. Bulman, ${ }^{43}$ where the accused were convicted of impaired driving causing death and dangerous driving causing death, and R. v. C.W., ${ }^{44}$ where the accused was convicted of unlawful act manslaughter and manslaughter by criminal negligence. The preferred approach would see the Crown withdraw one of the charges or the Court stay one of the charges upon conviction. $^{45}$

At present, most of the manslaughter offences found in the Criminal Code are redundant and entirely unnecessary. A single offence is all that is required. One proposal has suggested retaining the offence of "criminal negligence” and has provided the following definition: “A person is 'criminally negligent' where a reasonable person in the accused's situation would have been aware of the risk and the failure to avoid it constituted a marked and substantial

Criminal Code, supra note 6, ss. 220, 236. "The two provisions cover precisely the same ground and a person may be charged under either s. 220 or under s. 236. This makes very little sense”: Alan W. Mewett \& Morris Manning, Mewett \& Manning on Criminal Law, 3d ed. (Toronto: Butterworths Canada, 1994) at 732, n. 111.

R. v. Morrisey, 2000 SCC 39, [2000] 2 S.C.R. 90 at para. 61 [Morrisey].

Ibid. at para. 62. See also R. v. Tschetter, 2009 ABPC 125, [2009] A.J. No. 542 (QL) [Tschetter].

[1999] O.J. No. 1424 (Ct. J.) (QL).

In Tschetter, supra note 39, the accused was charged with five counts of manslaughter by criminal negligence and five counts of criminal negligence causing death. He was found guilty of manslaughter and the charges of criminal negligence causing death were stayed.

2007 ONCA 8, 83 O.R. (3d) 641.

2007 ONCA 169, 221 O.A.C. 210.

(2006), 209 O.A.C. 1.

In R. v. Coltman, 2009 ABPC 161, [2009] A.J. No. 652 (QL), the accused was originally charged with criminal negligence causing death. "[A] new Information was laid charging him with dangerous [driving] causing death" and the former charge was withdrawn (at para. 1). In R. v. Ryazanov, 2008 ONCA 677, 92 O.R. (3d) 81 [Ryazanov], when the accused "pleaded guilty to dangerous driving causing death ... [c] [harges of criminal negligence causing death ... were withdrawn” (at para. 37). In R. v. Lam (2003), 178 O.A.C. 275 [Lam], the accused "was found guilty ... of criminal negligence causing death and manslaughter as a result of an automobile accident” (at para. 1). The conviction for manslaughter was stayed by the Court. In R. v. Davies, 2008 ONCA 209, 234 O.A.C. 291, the accused was convicted of criminal negligence causing death and impaired driving causing death. At the sentencing hearing the trial judge stayed the impaired driving conviction. 
departure from the standard of care a reasonable person would have exercised in the circumstances."46

Unfortunately, rather than consolidating under one general offence we are much more likely to see the creation of new forms of manslaughter, often as a result of political considerations rather than sound criminal justice policy. A good example is provided by the response to public outrage over the carnage caused by street racers across Canada, particularly in Toronto and Vancouver. ${ }^{47}$ In May 2006, vowing to "protect the Canadian way of life" and to make safe those streets "on which mothers drive their kids to soccer practice,"48 Prime Minister Stephen Harper announced his government's intention to introduce new legislation. He specifically noted a number of recent incidents in which deaths were attributed to speed racing:

In January, three young men were killed on an east Vancouver Highway when their car spun into a ditch, splitting into two as it hit a power pole. Another passenger later died in hospital.

In that same month, Tahir Khan of Toronto, who was set to become a Canadian citizen only days later, was killed when his cab was involved in a horrific crash with a street racer.

And a man in Burnaby was killed when he lost control of his car and struck two oncoming vehicles, sending their occupants to hospital on Mother's Day. ${ }^{49}$

Parliament did enact several new offences, including criminal negligence causing death while street racing and dangerous operation of a motor vehicle causing death while street racing. ${ }^{50}$ It is important to note that when this legislation was introduced, the Criminal Code

46 Don Stuart, R.J. Delisle \& Allan Manson, Towards a Clear and Just Criminal Law: A Criminal Reports Forum (Scarborough: Carswell, 1999) at 116. See also Larry C. Wilson, "Too Many Manslaughters" (2007) 52 Crim. L.Q. 433 at 469 [emphasis in original], where a new, single crime of manslaughter was proposed: "It would consist of an actus reus (an act or omission causing death) and a mens rea (a marked departure or a marked and substantial departure from the standard of care of a reasonable person), and the penalty would continue as liability to imprisonment for life, with no minimum requirement for parole eligibility.” Other names for a single offence have also been suggested, e.g. "dangerous conduct causing death": see Stanley Yeo, "The Fault Elements for Involuntary Manslaughter: Some Lessons From Downunder” (2000) 43 Crim. L.Q. 291 at 301, 304.

$47 \quad$ "In the Toronto region, 35 people have died since 1999. There were an estimated 10 deaths from street racing in Canada in the first half of 2006": Dominique Valiquet, "Bill C-19: An Act to Amend the Criminal Code (Street Racing) and to Make a Consequential Amendment to the Corrections and Conditional Release Act” Legislative Summaries (Library of Parliament: Parliamentary Information and Research Service) at 3 [footnotes omitted], online: Parliament of Canada <www2.parl.gc.ca/ Content $\backslash$ LOP $\backslash$ LegislativeSummaries $\backslash 39 / 1 /$ c19-e.pdf $>$. The author cites several feature newspaper articles on street racing: see Jonathan Jenkins, "Street Racer Dies of Injuries; Raced with 2 Others on June 13" The Toronto Sun (20 June 2006) 28; Mark Hume, “Street Racing Blamed in Fatal Crashes” The Globe and Mail (28 June 2006) S1.

48 Office of the Prime Minister, “Address by the Prime Minister on Anti-Street Racing Legislation” (Vancouver, B.C., 25 May 2006), online: Office of the Prime Minister <http://pm.gc.ca/eng/media.asp? category $=2 \& i d=1179>$.

49 Ibid.

$50 \quad$ Criminal Code, supra note 6, ss. 249.2, 249.4(4). Three other offences were also created: dangerous operation not causing bodily harm or death, committed while street racing (s. 249.4(1)); dangerous operation causing bodily harm, committed while street racing (s. 249.4(3)); and "criminal negligence caus[ing] bodily harm," committed while street racing (s. 249.3). 
already contained offences for causing death by criminal negligence and dangerous operation of a motor vehicle allowing a number of successful prosecutions against street racers. ${ }^{51}$

Criminal negligence causing death, criminal negligence causing death while street racing, and dangerous operation of a motor vehicle causing death while street racing all have a maximum penalty of life imprisonment. ${ }^{52}$ The general offence of dangerous operation of a vehicle causing death carries a maximum penalty of 14 years. ${ }^{53}$ However, it is important to remember that, unlike murder, while manslaughter is subject to a maximum of life imprisonment there is no mandatory minimum sentence unless a firearm is used in the commission of the offence, in which case a minimum term of four years imprisonment is provided. ${ }^{54}$ A person found guilty of street racing causing death or any other form of manslaughter could receive a sentence ranging from life imprisonment to a small fine. ${ }^{55}$ Sentences for manslaughter exceeding 14 years are extremely rare and even if a sentence of life imprisonment was imposed, parole eligibility is set at seven years. ${ }^{56}$ In a recent decision from Ontario where an accused pleaded guilty to criminal negligence causing death while street racing, the original sentence consisted of "a conditional sentence of two years less a day, followed by two years’ probation, 140 hours of community service, a lifetime driving prohibition, a DNA order, and forfeiture of his automobile to the Crown [and] the conditional sentence included house arrest." ${ }^{, 57}$ The Crown appealed the conditional sentence; the Court of Appeal agreed and "impose[d] a sentence of 30 months." ${ }^{58}$ However, taking into account credit for pre-sentence custody and time already served under the conditional sentence, the Court concluded that the accused had already fully served the sentence. Thus "the sentence [was] varied to one of time served, to be followed by the two year term of probation. The lifetime driving prohibition and the other orders imposed by the sentencing judge remain[ed in place]." ${ }^{59}$ Anyone expecting significant increases in jail sentences for these new offences is likely to be disappointed.

See R. v. Tang, 2001 BCPC 62, [2001] B.C.J. No. 796 (QL); Lam, supra note 45; R. v. Khosa, 2003 BCCA 645, 190 B.C.A.C. 42 [Khosa]; R. v. Costa, 2007 ONCA 219, 44 M.V.R. (5th) 6; Ryazanov, supra note 45. For an example of a prosecution that failed see R. v. Menezes (2002), 50 C.R. (5th) 343 (Ont. Sup. Ct. J.). Criminal Code, supra note 6, ss. 220(b), 249.2, 249.4(4).

Ibid., s. 249(4).

Ibid., s. 236. The Supreme Court of Canada has held that the four-year minimum sentence does not violate the Canadian Charter of Rights and Freedoms, Part I of the Constitution Act, 1982, being Schedule B of the Canada Act 1982 (U.K.), 1982, c. 11: see R. v. Ferguson, 2008 SCC 6, [2008] 1 S.C.R. 96. For a good discussion of the factors to be considered in sentencing for manslaughter, see $R$. v. Hermiz (2007), 73 W.C.B. (2d) 698 (Ont. Sup. Ct. J.).

55 Community service orders have also been imposed following convictions for criminal negligence causing death and dangerous driving causing death: see Khosa, supra note 51; Ryazanov, supra note 45. Bill C-9, An Act to amend the Criminal Code (conditional sentence of imprisonment), 1st Sess., 39th Parl., 2006 (assented to 31 May 2007) [Bill C-9] amends s. 742.1. Bill C-9 provides that a person convicted of a serious personal injury offence, the maximum term of imprisonment being ten years or more, is not eligible for a conditional sentence. This would apply to criminal negligence causing death, dangerous operation causing death, and the street racing causing death offences. For sentence ranges, see Clayton C. Ruby et al., Sentencing, 6th ed. (Markham: LexisNexis Canada, 2004) at 669-90. See also Isabel Grant, Dorothy Chunn \& Christine Boyle, The Law of Homicide, looseleaf (Scarborough: Carswell, 1994) at 7-64-7-87; R. Paul Nadin-Davis, Sentencing in Canada (Toronto: Carswell, 1982). For parole eligibility, see Corrections and Conditional Release Act, S.C.1992, c. 20, s. $120(1)(b)$.

57 R.v. Nusrat, 2009 ONCA 31, 244 O.A.C. 241 at para. 4 [Nusrat]. The Court noted that the accused was eligible for a conditional sentence since the offence had occurred prior to the amendments to s. 742.1 of the Criminal Code. That amendment precludes a conditional sentence "where the offender is convicted of a serious personal injury offence" (at para. 33). See Bill C-9, supra note 55. Nusrat, ibid. at para. 6 . Ibid. at para. 74 . 
As noted, the new street racing offences do contain important provisions relating to driving prohibition orders. Under s. 259(2) of the Criminal Code, where an accused is found guilty of criminal negligence or dangerous operation of a vehicle, the sentencing judge has a discretionary power to make an order prohibiting the offender from driving. If convicted of a street racing offence the order is mandatory and for a first offence there is a minimum driving prohibition period of one year. ${ }^{60}$ The minimums and maximums increase for each subsequent offence ${ }^{61}$ In the case of criminal negligence causing death while street racing or dangerous operation of a vehicle causing death while street racing, a second offence results in an automatic lifetime prohibition against driving. ${ }^{62}$ Of course, rather than creating new offences, Parliament could have created the same mandatory penalties for the general offences of criminal negligence causing death and dangerous driving causing death where they involved street racing.

The street racing legislation was attacked as shameless political posturing. It was also suggested that this new initiative was unnecessary and unlikely to have any real impact on crime in Canada:

The effectiveness of the new maximum terms of imprisonment in practice may be doubtful. Given that it may be difficult, in some cases, to prove street racing, and that, it would appear, the courts will probably not impose the maximum sentences provided by the new offences in the bill, the Crown might prefer to use the existing offences in the Code - dangerous operation or criminal negligence.

Critics of the bill - like Josh Weinstein, a Winnipeg criminal lawyer and member of the Criminal Law Section of the Canadian Bar Association — argue, in general terms, that the various provincial laws and the existing provisions of the Criminal Code already apply to street racing, and that those provisions are sufficient for prosecuting and effectively punishing street racers.

Some people - including David MacAlister, an assistant professor of criminology at Simon Fraser University, and Tammy Landau, an associate professor of criminal justice at Ryerson University — believe that the new street racing offences and prison terms will not deter street racing participants, particularly young people seeking thrills. Street racing often occurs on impulse and the participants do not stop to consider the consequences of their acts. As well, Brian Bowman of the Toronto police says that the higher the risk, the more attracted some people will be to the activity.

In fact, the actual effectiveness of the bill to combat street racing is questioned. Some people believe that this is really a strategy to win political capital in regions where the Conservative Party needs more votes.

Some people claim that the new provisions will have little impact in practice. The only notable change is the increase in the maximum prison terms, which will probably not mean longer prison terms. As well, courts will probably never impose the maximum prison terms, let alone when it means life imprisonment. Consideration must also be given to the parole rules, which generally allow an offender to be released,

60 Criminal Code, supra note 6, s. 259(3.1).

61 Ibid.

$62 \quad$ Ibid., s. 259(3.4). 
subject to conditions, after serving a third of his or her sentence. These rules will not be changed in the case of street racing.

Some people think that the new street-racing offences will increase the number of criminal cases, and thus lead to higher costs for the justice system and taxpayers. ${ }^{63}$

Justice Minister Vic Toews responded to the criticism by arguing that even if the street racing provisions were not applied, the new maximum prison terms and mandatory driving prohibitions would send a powerful message to the public that street racing will not be tolerated. ${ }^{64}$ The street racing offences were described as an important educational tool. ${ }^{65}$ Minister Toews also described criminal negligence and dangerous driving as included offences and noted that if the prosecution was unable to prove a street race "but [had] proven all the essential elements of either dangerous driving or criminal negligence," the accused could be convicted of one of those offences. ${ }^{66}$ This of course begs the question why the Crown would bother trying to secure a conviction under one of the new provisions.

The redundant nature of street racing manslaughters is well illustrated by one of the cases referred to by Prime Minister Harper: the decision of Ryazanov. ${ }^{67}$ A terrible accident occurred in Toronto on 24 January 2006, approximately one year before the new street racing offences received Royal Assent. ${ }^{68}$ Two 18-year-olds were driving their respective MercedesBenz automobiles at variable speeds between 80 and 140 kilometres per hour on a road with a speed limit of 60 kilometres per hour. Witnesses described their vehicles as passing one another with "little space between them." ${ }^{69}$ One of the accused struck another vehicle, killing the driver, an immigrant from Pakistan working as a taxi driver to support his extended family. Both accused were charged with criminal negligence causing death and dangerous driving causing death. One of the accused was also charged with leaving the scene of an accident. Both accused were 18 years old at the time of the accident and had just completed high school. Neither had a criminal record nor a history of substance abuse, and they "were supported by stable families, had expressed remorse and accepted full responsibility for their actions."70 After negotiations with the Crown, they pleaded guilty to dangerous driving causing death and the remaining charges were withdrawn. The accused were sentenced to

Valiquet, supra note 47 at 14, 22 [footnotes omitted]. The author cites a number of negative comments in the media: see Campbell Clark \& Tenille Bonoguore, “The Street-Racing Crackdown: Federal bill aims to make street racing a criminal offence and calls for tougher sentences for drivers — Law won't deter people from racing, experts say; Harsher penalties could even encourage culture of dangerous driving, police warn” The Globe and Mail (16 June 2006) A4; Janice Tibbetts, "Street racers on gov't radar: Ottawa introduces tough new legislation aimed at slowing drivers" The [Saskatoon] StarPhoenix (16 June 2006) C13; Susan Ruttan, "Street racing law 'politically motivated': Proposed legislation makes it harder for Crown to win its case, experts say” Edmonton Journal (17 June 2006) A7; C. Moore, "Harsh Laws No Answer to Street Racing” The Halifax Daily News (19 June 2006) 10; Sharon Ho, "Street 'symbolism' and cynicism; Prof: No deterrent in fed racing law and overworked courts will end up paying price” The Toronto Sun (16 June 2006) 2; Dan Gardner, "Street legislation will do nothing" The Windsor Star (29 June 2006) A8. The Criminal Code, ibid., s. 2, defines street racing as “operating a motor vehicle in a race with at least one other motor vehicle on a street, road, highway or other public place."

House of Commons Debates, Vol. 141, No. 057 (2 October 2006) at 3470-74 (Hon. Peter Milliken).

Ibid. at 3473.

Ibid. at 3471.

Ryazanov, supra note 45.

Bill C-19, An Act to amend the Criminal Code (street racing) and to make a consequential amendment to Corrections and Conditional Release Act, 1st Sess., 39th Parl., 2006 (assented to 14 December 2006). Ryazanov, supra note 45 at para. 7.

Ibid. at para. 14. 
“conditional sentence[s] of two years less a day,” which included 12 months of house arrest, plus probation and driving prohibitions of four years. ${ }^{71}$ The Crown successfully appealed the sentence. The conditional sentences were varied to provide for house arrest through the term of the orders, and the driving prohibition was increased to seven years.

One of the questions addressed by the Court of Appeal was, "[d]id the sentencing judge err by failing to consider whether the respondents were racing?”72 In answering this question, Epstein J.A. stated:

Even though the sentencing judge mistakenly stated that the Crown was not relying on evidence of racing, he nonetheless gave proper consideration to the facts that could support the Crown's contention. He acknowledged that the respondents were travelling at speeds of more than two times the legal limit, while switching from one lane to another and that this conduct continued over a distance of one and a half kilometres. I am satisfied that the sentencing judge considered the factors that the Crown argued amounted to racing, although in his reasons he did not individually list each aspect of the respondents' driving behaviour.

"Racing" is not defined in the Criminal Code.

Here, the sentencing judge had only the agreed statement of facts to assist on the issue of whether the respondents were racing.... The agreed statement of facts did not include a statement that the respondents were attempting to out-distance each other or that they were preventing each other from passing. There was no mention of abrupt lane changes or bold manoeuvring consistent with racing behaviour. In the circumstances, the agreed statement of facts did not support an inference of racing on the standard of proof beyond a reasonable doubt.

In any event, I do not regard it as important to assign a label to the respondents' conduct in order to determine the appropriate sentence. I agree with the comments at para. 27 in R. v. Khosa (2003), 180 C.C.C. (3d) 225 (B.C.C.A.), leave to appeal to S.C.C. refused, [2004] S.C.C.A. No. 38, that "[i]t is more important to focus on the particulars of the offence and the offenders rather than to rely simply on the label 'street race' to determine how to sentence the respondents.” That is precisely what the sentencing judge did in this case. ${ }^{73}$

This decision clearly supports those who argue that the introduction of "street racing manslaughter" provisions was unnecessary. Street racers who cause death have been, and can continue to be prosecuted for dangerous driving causing death under s. 249(4) of the Criminal Code. Criminal negligence causing death under s. 220 of the Criminal Code is another alternative, ${ }^{74}$ although that offence has an elevated fault requirement or mens rea

Ibid. at para. 26.

Ibid. at para. 61.

Ibid. at paras. 61, 64-66.

In the Khosa case, supra note 51, which was cited in Ryazanov, ibid., a pedestrian was killed by two young street racers who were convicted of criminal negligence causing death rather than dangerous driving causing death. Both accused received "conditional sentences of two years less a day, followed by probation for three years" (at para. 2). The terms "imposed as part of the conditional sentences 
relative to the offence of dangerous driving, thus making it potentially more difficult to secure a conviction. On the other hand, as implied by the discussion in the Ryazanov case, it will be more difficult to convict of "dangerous operation by street racing" than "dangerous operation" given that the Crown must prove the additional circumstance of street racing beyond a reasonable doubt. All of these factors reinforce the argument that it would be preferable and much more logical to either create a new offence that encompasses all these situations, or recognize that the existing concept of criminal negligence is broad enough to accomplish that objective.

In any event, the creation of new forms of manslaughter will, if nothing else, add to the confusion in the area. For example, criminal negligence is regarded as a more serious offence than dangerous driving causing death. The two offences have different penalties (14 years versus life imprisonment) and a different fault element (marked departure for dangerous driving versus marked and substantial departure for criminal negligence). Also, dangerous driving causing death is included in manslaughter and criminal negligence causing death. ${ }^{75}$ Yet both dangerous driving causing death while street racing and criminal negligence causing death while street racing carry the same maximum penalty of life imprisonment. Does that mean that dangerous driving causing death while street racing has the same fault element (marked and substantial departure) as criminal negligence causing death while street racing?

For politicians intent on trumpeting their "tough on crime" credentials, there will always be a great temptation to create new offences and increase penalties. In 1985, changing public perceptions about drinking and driving resulted in a new offence: impaired driving causing death. ${ }^{76}$ Prior to the change, drunk drivers were convicted of criminal negligence. ${ }^{77}$ Now we have charges under street racing causing death and minimum sentences where a firearm is involved. ${ }^{78}$ In the immediate future, we can anticipate other new and unnecessary additions to the long list of manslaughters; I would suggest that environmental degradation causing death is a likely candidate.

included house arrest with limited exceptions and an order to perform 240 hours of community work over a period of 18 months.” They also received a five-year driving prohibition (ibid.). As noted in supra note 55, the option of conditional sentences following a conviction for criminal negligence causing death will no longer be available. In Beatty, supra note 1, Charron J. (Bastarache, Deschamps, Abella, Rothstein JJ. concurring) stated that criminal negligence is "higher on the continuum of negligent driving” than dangerous driving (at para. 48). Chief Justice McLachlin (Binnie, LeBel JJ. concurring) noted that there has been considerable debate "regarding the approach to actus reus and mens rea in driving cases where the offence charged is criminal negligence, rather than dangerous driving” (at para. 79). Since the charge in Beatty was dangerous driving causing death, McLachlin C.J.C. stated, "[i]n this case, the Court does not have to rule on the elements of the offence for a driving offence charged as criminal negligence, and these reasons should not be read as deciding that issue” (ibid.). In J.F., supra note 5, the Supreme Court made it very clear that criminal negligence, by requiring a marked and substantial departure from the conduct of a reasonable person, requires more fault than other objective crimes which require proof of a marked departure only.

Criminal Code, supra note 6, s. 662(5). See R. v. Sharp (1984), 3 O.A.C. 26; R. v. Waite, [1989] 1 S.C.R. 1436.

Criminal Law Amendment Act, R.S.C. 1985 (1st Supp.), c. 27.

See R. v. Torrie (1967), 2 O.R. 8 (C.A.).

Criminal Code, supra note 6, s. 236. 


\section{The MENS REA OF MANSLAUghter}

Most of the discussion and controversy surrounding the mens rea or fault element analysis for the crime of manslaughter has focused on ss. 220 and 222(5) of the Criminal Code. Section 220 creates the offence of criminal negligence causing death and s. 222(5) identifies the different types of culpable homicides that constitute manslaughter. Two of those culpable homicides, unlawful act culpable homicide and criminal negligence culpable homicide, often form the basis for a manslaughter charge.$^{79}$ On the other hand, manslaughter as a result of threats or wilful frightening is virtually unknown. ${ }^{80}$ First, appropriate fact situations will be extremely rare. ${ }^{81}$ Second, in many instances where the conduct involves threats or wilful frightening, the evidence will suggest sufficient fault (an intention to cause death or, alternatively, an intention to cause bodily harm that the accused knew was likely to cause death) to warrant a charge of murder pursuant to s. 229 of the Criminal Code. Finally, issuing threats or wilful frightening will almost certainly qualify as an unlawful act or criminal negligence thereby creating the more likely scenario of a charge based on ss. 222(5)(a), 222(5)(b), or 220.

In 1993, the Creighton ${ }^{82}$ decision established a two-tiered fault element for the offence of unlawful act manslaughter. The Crown must prove, beyond a reasonable doubt, both (1) the mens rea of the unlawful act, and (2) "objective foreseeability of the risk of bodily harm which is neither trivial nor transitory, in the context of a dangerous act. Foreseeability of the risk of death is not required." ${ }^{\text {"3 }}$

Since the unlawful act for unlawful act manslaughter may be any offence other than an offence of absolute liability, a provincial strict liability offence would qualify. When a person is charged with a strict liability offence that person, rather than the Crown, carries the legal burden of proof with regard to the fault element. ${ }^{84}$ The accused is required to show, on a balance of probabilities, that he or she acted as a reasonable person; that is, he must demonstrate due diligence. ${ }^{85}$ This is a standard of civil negligence. Thus, there are both conceptual and practical problems when the unlawful act alleged by the Crown is an offence of strict liability. With regard to this predicate offence, does the accused have the legal burden of proof on a balance of probabilities? Or does the burden shift to the Crown, and if so, what is the standard of proof, balance of probabilities or beyond a reasonable doubt?

The Supreme Court did not have to directly address these questions in the Creighton decision since the predicate offence was "trafficking" under the federal Narcotic Control $A c t,{ }^{86}$ not a strict liability offence. However, McLachlin J. (as she then was) did state that "a predicate offence involving carelessness or negligence must also be read as requiring a 'marked departure' from the standard of the reasonable person." ${ }^{\text {'7 }}$ That comment played an

Ibid., s. 222(5)(a)-(b).

Ibid., s. 222(5)(c)-(d).

See R. v. Harrison, [1945] 3 D.L.R. 122 (B.C.C.A.); R. v. Graves (1913), 9 D.L.R. 589 (S.C.C.). Supra note 32.

Ibid. at 45.

R. v. Sault Ste. Marie (City of), [1978] 2 S.C.R. 1299.

Ibid.

R.S.C. 1985, c. N-1.

Creighton, supra note 32 at 59. 
important role in the subsequent decision of $R$. v. Curragh Inc., ${ }^{88}$ better known as the Westray Mining case. In that case the alleged unlawful acts consisted of violations of provincial occupational health and safety as well as mine safety regulations. These were provincial strict liability offences that, if prosecuted on their own, would require the accused to establish due diligence on a balance of probabilities. However, because the charge was manslaughter, the Court held that the Crown was required to prove all elements of the offence beyond a reasonable doubt, including the fault element, a "marked departure" from the standard of a reasonable person. ${ }^{89}$ The elevation in status of the unlawful act from provincial offence to predicate offence was highlighted by the Court's finding that a manslaughter charge could proceed even where the predicate offence itself could not be prosecuted due to the expiration of a limitation period. ${ }^{90}$

Thus, in those cases where the predicate offence is a strict liability offence, the fault element will be elevated from simple negligence to a "marked departure" and the Crown will be required to prove that mens rea beyond a reasonable doubt. Where the unlawful act has a fault element of penal negligence or subjective fault, the Crown will be required to prove that particular fault element beyond a reasonable doubt. ${ }^{91}$ Examples of offences that have a subjective fault requirement and have served as an unlawful act on a manslaughter charge include assault, ${ }^{92}$ mischief, ${ }^{93}$ unlawful confinement, ${ }^{94}$ and trafficking in a controlled substance. $^{95}$

At some point the Supreme Court may wish to revisit the question of whether or not an offence of absolute liability can serve as a predicate offence. The decision of $R$. $v$. Transport Robert (1973) Ltée $e^{96}$ provides an example. The case was concerned with the Ontario provincial offence of being an owner of a commercial motor vehicle from which a wheel separated while on a public highway. ${ }^{97}$ The offence was determined to be an offence of absolute liability. Thus, where an accused is charged with this offence, a conviction will follow upon proof of actus reus. There is no requirement for proof of fault. However, if a death resulted (there was no death in this particular case) and the absolute liability offence served as the unlawful act on a charge of unlawful act culpable homicide, the Crown would be required to prove not only the actus reus but also the mens rea in the form of a marked departure from the standard of a reasonable person. ${ }^{98}$ Again, it is important to emphasize that where a provincial offence is the unlawful act in an unlawful act manslaughter charge, that

(1993), 125 N.S.R. (2d) 185 (Prov. Ct.).

Ibid. at para. 12.

Ibid. at para. 7.

In R. v. Gosset, [1993] 3 S.C.R. 76 [Gosset], the unlawful act was careless handling of a firearm. Because the careless handling was an offence contrary to s. 86(2) of the Criminal Code and therefore viewed as “[n]egligence in a criminal setting,” the fault element was penal rather than civil negligence (at 93). See also R. v. Gunning, 2005 SCC 27, [2005] 1 S.C.R. 627.

R. v. Garrison (1999), 125 O.A.C. 260; R. v. Couperthwaite, 2006 MBQB 111, 203 Man. R. (2d) 261. See T. (K.), supra note 33. Justice Hamilton stated that "[i]t was essential that the Crown identify the unlawful act to be relied upon and for the judge to determine whether the Crown had proved the actus reus and mens rea of that offence beyond a reasonable doubt” (at para. 19).

R. v. J.P.G., [1996] O.J. No. 4778 (Ct. J. (Prov. Div.)) (QL). Decisions in Alberta and Ontario have determined unlawful confinement to be an offence of general intention: see R. v. B. (S.J.), 2002 ABCA 143, 312 A.R. 313; R. v. B. (E.) [2006] O.J. No. 1864 (Sup. Ct. J.) (QL).

Worrall, supra note 26.

(2003), 68 O.R. (3d) 51 (C.A.).

See Highway Traffic Act, R.S.O. 1990, c. H.8, s. 84.1.

This approach was suggested by Grant, Chunn \& Boyle, supra note 56 at 4-14-4-15. 
offence has become part of the actus reus and mens rea of the crime. Accordingly, the fault element will be that of a criminal offence - in this case, a marked departure from the conduct of a reasonable person.

The approach suggested above has gained support from the decisions in Beatty and J.F. Prior to these decisions, several leading academics had argued that there was no "marked departure" component to the fault element for unlawful act manslaughter. ${ }^{99}$ Others disagreed and maintained that the element of "dangerousness" described in Creighton was the equivalent of penal negligence or marked departure. ${ }^{100}$ Foresight of bodily harm in the context of a dangerous act "that is likely to injure another person" certainly seemed to suggest something a little more substantial than simple negligence. ${ }^{101}$ The Supreme Court has settled the issue. In Beatty, the accused was charged with three counts of dangerous operation of a motor vehicle causing death under s. 249(4) of the Criminal Code ${ }^{102}$ The Court held this was an offence of penal negligence with an objective mens rea, a "marked departure" from the norm. On the facts of the case the Court further held that "a momentary lapse of attention" did not satisfy the mens rea requirement. ${ }^{103}$ In reaching that decision the Court held that "where liability for penal negligence includes potential imprisonment ... the distinction between civil and penal negligence acquires a constitutional dimension."104 The fundamental principles of criminal justice require a modified objective test: "proof of a marked departure from the standard of care that a reasonable person would observe in all the circumstances.... [I]t is only when there is a marked departure from the norm that objectively dangerous conduct demonstrates sufficient blameworthiness to support a finding of penal liability." 105 Professor Don Stuart describes the significance of this decision for the offence of unlawful act manslaughter:

This major ruling in $R$. v. Beatty ... on dangerous driving is written in language which applies to any crime requiring objective fault where there is a risk of imprisonment. For such crimes the Court holds that, in contrast to civil liability for negligence, principles of fundamental justice under section 7 of the Charter require proof of a marked departure from the objective norm.

See Stuart, Canadian Criminal Law, supra note 28 at 271; David Paciocco, "Subjective and Objective Standards of Fault for Offences and Defences” (1995) 59 Sask. L . Rev. 271 at 281. Professor Stuart did state his support for the contrary position saying: "[i]t has long been my view that in cases of crimes objective responsibility should be limited to gross departures causing serious harm, with such offences carrying lesser penalties": Don Stuart, “The Supreme Court Drastically Reduces the Constitutional Requirement of Fault: A Triumph of Pragmatism and Law Enforcement Expediency” (1993) 15 C.R. (4th) 88 at 99.

Patrick Healy, “Repeal Criminal Negligence” (1995) 37 Crim. L.Q. 205 at 208. Professor Healy writes: "It seems settled that the standard applicable to the underlying offence, whether it is an endangering offence or some other unlawful act, must be a marked departure from reasonable conduct” (at 210). Professors Grant, Chunn, and Boyle, in their comment on Creighton, state: "This case established that the requisite level of fault in unlawful act manslaughter is a marked departure from the standard of the reasonable person”: Grant, Chunn \& Boyle, supra note 56 at 4-14. Creighton, supra note 32 at 43.

102 Beatty, supra note 1. Section 249(4) of the Criminal Code also covers dangerous operation of vessels and aircraft: see R. v. Haig (2009), 80 M.V.R. (5th) 142 (Ont. Sup. Ct. J.), where the accused was found guilty of dangerous operation of a vessel causing death. The vessel was a 14 -foot motor boat. Beatty, ibid. at paras. 51-53.

$104 \quad$ Ibid. at para. 6.

105 Ibid. at para. 36 [emphasis in original]. 
If a marked departure from the objective norm is the minimum Charter standard for criminal offences resulting in imprisonment, this should also govern all so-called crimes based on predicate offences ... namely, according to the Supreme Court, unlawful act manslaughter (s. 22[2](5)(a)), unlawfully causing bodily harm (s. 269), aggravated assault (s. 268) and, in lower court rulings, assault causing bodily harm (s. 267). ${ }^{106}$

In J.F., unlike Beatty, the Court was actually dealing with an offence of unlawful act culpable homicide. In fact, the accused was charged with two offences arising from the death of his son: manslaughter by criminal negligence and manslaughter by failing to provide the necessaries of life. In his comment on the case, Professor Stuart expressed surprise that the Crown chose to proceed with two counts of manslaughter. In Stuart’s opinion, “[p]rosecutors should have exercised better judgment and ... laid just one count.” ${ }^{107}$ At trial, J.F. was convicted of manslaughter by criminal negligence but acquitted on the second count. The Ontario Court of Appeal overturned the conviction and ordered a new trial on the charge of manslaughter by criminal negligence on the basis that the verdicts were inconsistent. On further appeal the Supreme Court of Canada agreed that the verdicts were inconsistent but rather than ordering a new trial entered an acquittal on the charge of manslaughter by criminal negligence. Justice Fish (McLachlin C.J.C., Binnie, Abella, Charron, Rothstein JJ., concurring; Deschamps J. dissenting) concluded that the accused "was acquitted and convicted by the same jury at the same trial of the same offence committed in the same way against the same victim." ${ }^{108}$ He found that the actus reus for both forms of manslaughter was identical $^{109}$ and that the fault element for the unlawful act manslaughter was "a marked departure from the conduct of a reasonably prudent parent in circumstances where it was objectively foreseeable that the failure to provide the necessaries of life would lead to a risk of danger to the life, or a risk of permanent endangerment to the health, of the child."110 However, the real significance of the decision was the finding that although the fault requirements for the two offences were "similar," criminal negligence was a "more serious" offence demanding proof of a higher level of fault. ${ }^{111}$

Since the concept of criminal negligence was first incorporated into Canadian criminal legislation in 1955, the courts have struggled to find the appropriate fault element. ${ }^{112}$ In fact, as noted above, it is only recently that the Supreme Court has determined that "criminal negligence" is indeed a fault element and not part of the actus reus. ${ }^{113}$ The early cases made

Don Stuart, “Beatty: Charter Standard of Marked Departure for All Crimes of Negligence” (2008) 54 C.R. (6th) 33 at 33-34 [footnotes omitted]. Professor Stuart restates his earlier position that unlawful act culpable homicide requires, "in addition to proof of the fault for the underlying [offence], only proof of dangerousness in the form of objective foresight of non-trivial bodily harm” (at 34). He insists "[ $t$ ]here is no marked departure test unless the predicate offence is based on negligence" (at 34). Since strict liability offences are "based on negligence," a marked departure test would apply and only offences of absolute liability would be precluded. Don Stuart, “F.(J.): Three Degrees of Negligence” (2008) 60 C.R. (6th) 240 at 241 [Stuart, “F.(J.)”]. J.F., supra note 5 at para. 1.

Ibid. at para. 2.

R. v. Naglik, [1993] 3 S.C.R. 122 at 143, cited in J.F., ibid. at para. 8 [emphasis added].

J.F., ibid. at para. 4. Justice Fish added: "As I have already mentioned, the verdicts at trial signify that a lesser degree of fault was not established, while a greater degree of fault was proven beyond a reasonable doubt. Even if the jury treated the fault requirements as equivalent, the verdicts would remain inconsistent because, as we have seen, the actus reus for both offences was, on the facts of this case, identical. In either case, the respondent's conviction cannot stand” (at para. 17). 
it clear that "something more" than civil negligence was required. The "something more" tended to be either traditional subjective mens rea or gross negligence, which was defined as "a very high departure from the standard of care expected of the reasonable person."114 When the issue came squarely before the Supreme Court in the 1980s, the Court managed a tie, as three judges supported subjective fault and an equal number supported objective fault. ${ }^{115}$ Subsequent decisions showed a clear preference for an objective test, but there remained some confusion over whether the standard was the same as that used for other objective crimes (a marked departure) or whether a marked and substantial departure was required. ${ }^{116}$ The issue was further clouded by decisions that seemed to fuse the various tests. For example, in Willock, a case involving a car accident, the Ontario Court of Appeal held that the fault element for criminal negligence was a marked and substantial departure and that fault could be shown if the accused "deliberately jerked the steering wheel to cause the vehicle to swerve."117 This approach suggested the use of a subjective fault form (“deliberately") in determining the requisite objective fault (a marked and substantial departure).

The Supreme Court has directly addressed these questions. In Beatty, Charron J. rejected any suggestion that the Willock decision represented a return to subjective fault for crimes of criminal negligence. ${ }^{118}$ Rather, she held that the deliberate or intentional act of an accused is “relevant to a court's objective assessment of whether or not conduct constitutes a marked [and substantial] departure from the norm." ${ }^{\text {119 }}$ For example, if a person deliberately drove into another vehicle for the sole purpose of frightening passengers in that vehicle, that would demonstrate a significant level of objective fault. ${ }^{120}$ In J.F., Fish J. made it equally clear that the mens rea requirement for criminal negligence is more than civil negligence and it is more than a marked departure. ${ }^{121}$ The mens rea for criminal negligence is a "marked and substantial departure.”122

Stuart, Canadian Criminal Law, supra note 28 at 264-65. Grant, Chunn \& Boyle, supra note 56 at 4-25 state: "Prior to Tutton [supra note 33], the case law was confused, although it is fair to say that in general lower courts tended to use an objective test while the Supreme Court of Canada tended to favour a subjective approach to criminal negligence.”

See Tutton, ibid. Professor Stuart notes in his text, ibid. at 266, n. 717, that the tie was made possible because two justices were ill and a third, Estey J., did not participate in the decision.

The "marked departure" test was supported in Creighton, supra note 32 at 43, 59, McLachlin J.; Morrisey, supra note 38 at para. 19, Gonthier J. Several provincial Court of Appeal decisions supported a test of "marked and substantial departure" for criminal negligence: see R. v. Bartlett (1998), 108 O.A.C. 350; R. v. Palin (1999), 135 C.C.C. (3d) 119 (Qc. C.A.), leave to appeal to S.C.C. refused, 134 C.C.C. (3d) vi; L. (J.), supra note 33.

Willock, supra note 33 at para. 32. The Court did not cite an earlier Court of Appeal decision, R. v. Sharp (1984), 3 O.A.C. 26, where Morden J.A. suggested that the word "deliberate" should not be equated with intention (rather, it was concerned with "conscious and volitional driving" and further, it would be best if the word "deliberate" was not used in a charge of criminal negligence (at paras. 18, 20)). In $R$. v. Piluke (1993), 60 W.A.C. 1 (B.C.), aff'd [1995] 1 S.C.R. 443, the British Columbia Court of Appeal held that the trial judge's reference to “'deliberate' conduct” was an error (at paras. 20, 22). Beatty, supra note 1 at para. 47.

Ibid.

Ibid.

J.F., supra note 5.

Ibid. at para. 9 [emphasis omitted]. 
Thus, we now have three levels of objective fault: mere departure; ${ }^{123}$ marked departure; and marked and substantial departure. The mere departure, or simple negligence, standard will be used for strict liability offences, marked departure will be the test for crimes of penal negligence, and marked and substantial departure will be the mens rea for crimes of criminal negligence. ${ }^{124}$ It is somewhat ironic that criminal negligence has become the most serious of the objective crimes since it was initially introduced in response to a concern that jurors were more likely to convict of something called criminal negligence than the more serious sounding manslaughter. ${ }^{125}$

The major task now awaiting the Supreme Court will be to provide some guidance on the distinction between the different fault forms. Previous experience suggests that there will be extensive debate about where to draw the line. Professor Stuart provides an excellent example in his comparison of Anderson ${ }^{126}$ and Reed. ${ }^{127}$ Regarding Anderson, Stuart describes the Supreme Court's "startling determination that one who went through a red light while impaired at over twice the legal limit, killing a passenger, had not been criminally negligent" while, in Reed, he notes that the same Court "had no difficulty confirming convictions on three counts of dangerous driving causing death where the accused had been driving on the wrong side of the road more than $20 \mathrm{~km} / \mathrm{hr}$. over the speed limit.”128

Two recent cases provide another example of how difficult it will be to predict outcomes based on degrees of negligence. In Robinson, a case from southern Ontario, the accused was charged with two counts of criminal negligence causing death and two counts of dangerous driving causing death after he crashed into another vehicle, killing both occupants. ${ }^{129}$ The accused had bipolar disorder and had not taken his medication. There had been a previous incident involving erratic driving and the accused was well aware of the fact that he should not have been driving in his condition. His speed was estimated at over 150 kilometres per hour, he failed to notice several signs asking drivers to slow down, and he did not see that the traffic in front of him was stopped. There were no skid marks and there was no evidence of braking or evasive manoeuvres. When he ran into the back of the stopped vehicle the collision was so severe that the two vehicles were described as being "fused as one." 130 The accused was found guilty of dangerous driving causing death but not guilty of criminal

This is the description used by Charron J. in Beatty, supra note 1 at para. 7. For recent examples of cases that followed Beatty and held that the driving in question was mere negligence rather than a marked departure see R. v. Lamoureux, 2008 SKQB 342, 323 Sask. R. 198; R. v. McCaughan, 2009 MBCA 14, 236 Man. R. (2d) 188; R. v. Palmer, 2009 ONCJ 23, [2009] O.J. No. 474 (QL). See Stuart, “F.(J.),” supra note 107 at 241.

J.C. Martin, The Criminal Code of Canada (Toronto: Cartwright \& Sons Ltd., 1955) at 370. See also A.J. MacLeod \& J.C. Martin, "Offences and Punishments Under the New Criminal Code" (1955) 33 Can. Bar Rev. 20 at 31; Mewett \& Manning, supra note 37 at 732, n. 111. For a concise summary of the history of manslaughter, criminal negligence, and dangerous driving see the judgment of Fraser J. in Tschetter, supra note 39 at paras. 88-94.

R. v. Anderson, [1990] 1 S.C.R. 265 [Anderson].

R. v. Reed, [1998] 1 S.C.R. 753 [Reed].

Stuart, Canadian Criminal Law, supra note 28 at 268, n. 726 [emphasis in original].

R. v. Robinson (2007), 45 M.V.R. (5th) 118 (Ont. Sup. Ct. J.) [Robinson]. The Court noted that there was no need to charge the counts of dangerous driving separately as dangerous driving is an included offence in criminal negligence (at para. 2). See Criminal Code, supra note 6, s. 662(5). R. v. Trakas, 2008 ONCA 410, 241 O.A.C. 52 and R. v. K.L., 2009 ONCA 141, 248 O.A.C. 260 are two other recent cases from Ontario where the accused was found guilty of dangerous driving causing death but acquitted of criminal negligence causing death. In R. v. Du Jardin (2008), 72 M.V.R. (5th) 90 (Ont. Sup. Ct. J.), the accused was convicted of dangerous driving causing death but acquitted of impaired driving causing death.

Robinson, ibid. at para. 53. 
negligence. Compare that decision to the case of Tschetter, a 2009 decision from Alberta. ${ }^{131}$ The accused was driving a cement truck and crashed into the rear end of a vehicle stopped at a red light. All five people in the car were killed. At the time of the collision the cement truck was estimated to be travelling at 105 to 120 kilometres per hour in an 80 kilometre per hour speed zone. There was some evidence that the driver had attempted to brake prior to the accident. The Court also found that, prior to the accident, the accused had been driving in an aggressive and dangerous manner, passing other vehicles at a high rate of speed. The Court held this conduct amounted to a marked and substantial departure and he was convicted of manslaughter by criminal negligence.

In R. v. Penner ${ }^{132}$ the Court of Queen's Bench of Alberta held that evidence of excessive speed alone can constitute the requisite fault (a marked departure) for the crime of dangerous driving causing death. A decision from Newfoundland suggests that additional factors will be required to elevate dangerous driving to criminal negligence:

In criminal negligence cases, the courts have generally found additional acts of negligence combined with excessive speed factor, for example, driving while impaired, racing, driving on the wrong side of the road, reckless passing and intentionally running red lights or stop signs. It is such combinations that increase the extent of the marked departure from the standard of care of a reasonable person that places the offence into the category of criminal negligence. ${ }^{133}$

In Beatty, Charron J. describes the distinction between civil negligence and penal negligence as a "question of degree"134 and notes that criminal negligence is higher on the "negligence continuum" than penal negligence. ${ }^{135}$ Comparing criminal negligence to a crime of penal negligence (manslaughter by failing to provide the necessaries of life), Fish J. noted that "[t]he fault element, though not identical, was essentially common." ${ }^{36}$ He described criminal negligence as "a more serious offence, signifying more blameworthy conduct."137 Professor Stuart describes the marked and substantial departure test for criminal negligence as "worse than gross negligence." ${ }^{38} \mathrm{He}$ is no doubt correct when he predicts that "[t]his new normative distinction between degrees of gross negligence seems likely to confuse and cause head-scratching by lawyers, judges and jurors."139

Our expanded definition of manslaughter, which includes all culpable homicides causing death other than murders or infanticides, will require a number of unique, charge specific fault elements. Sections 222(5)(a) and (b) of the Criminal Code require causing death by "threats" or "wilfully frightening," thereby necessitating proof of subjective fault. ${ }^{140}$ While dangerous driving causing death is a crime of penal negligence requiring proof of a marked departure using the modified objective test outlined initially in Hundal and adopted in Beatty,

Tschetter, supra note 39.

2009 ABQB 259, 84 M.V.R. (5th) 255. The Court cites several earlier decisions including $R$. $v$. Richardson, 2007 ABCA 68, 404 A.R. 42.

R. v. Brake (J.P.), 2008 NLTD 102, 276 Nfld. \& P.E.I.R. 271 at para. 45.

Beatty, supra note 1 at para. 7 .

Ibid. at para. 48, citing Willock, supra note 33 at para. 31.

J.F., supra note 5 at para. 3.

Ibid. at para. 13.

Stuart, "F.(J.)," supra note 107 at 241.

Ibid. at 240.

Criminal Code, supra note 6, s. 222(5). 
impaired driving causing death has a subjective fault element requiring an intention to assume care or control after the voluntary consumption of alcohol or a drug. ${ }^{141}$ Causing death by criminal negligence (street racing) requires proof of a marked and substantial departure, but dangerous operation of a motor vehicle while street racing has a lesser fault element of a marked departure. ${ }^{142}$ Causing death while operating a motor vehicle in a dangerous manner and fleeing a police officer requires a specific intent to evade the police. ${ }^{143}$ Causing death through a breach of the duty to properly handle explosives is based on the failure to exercise "reasonable care," thus suggesting an objective evaluation elevated to the category of penal negligence (a marked departure) following the reasoning in Beatty. ${ }^{144}$ On the other hand, the offences of neglecting to obtain assistance in childbirth leading to death and the use of traps causing death both contain the phrase "with intent," indicating a requirement for proof beyond a reasonable doubt of full subjective fault. ${ }^{145}$ For the offence of failing to guard an opening in ice causing death, it has been suggested that "knowledge" is an "essential element." ${ }^{146}$ Corporate responsibility for negligence-based culpable homicide can be based on objective criteria. ${ }^{147}$

Section 21 of the Criminal Code provides the opportunity for a conviction based on aiding and abetting manslaughter. In R. v. Jackson, the Supreme Court held that there could be a conviction for manslaughter where a person "aids and abets another person in the offence of murder, where a reasonable person in all the circumstances would have appreciated that bodily harm was the foreseeable consequence of the dangerous act which was being undertaken." 148 This decision suggests an objective test although, as noted by Professor Stuart, the Court did not address the question of whether there was an initial requirement of an intent to aid. ${ }^{149}$ Support for a subjective approach is found in R. v. Mariani, a 2007 decision of the Ontario Court of Appeal:

In the ensuing part of the charge on this point, the trial judge essentially instructed the jurors they must be satisfied beyond a reasonable doubt on four elements in order to convict one or more of the accused of being a party to the offence of manslaughter. He did so - properly, in my view - by dealing first with aiding and abetting (i.e., the "party” issue, which encompassed the first three elements) and then turning to the objective element of manslaughter (the fourth element).

In relation to aiding and abetting, the trial judge told the jurors they must be satisfied (i) that the person alleged to have been a party was present at the scene of the assault or was close to the victim when he was being kicked, (ii) that the presence or conduct had the effect of aiding or encouraging the perpetrators to commit the offence, and (iii) that the person alleged to have been a party must have intended to aid or encourage the assault.

Hundal, supra note 2. See Criminal Code, ibid., s. 249(4). There is no requirement of intent to drive: R. v. Toews, [1985] 2 S.C.R. 119; see Criminal Code, ibid., s. 255(3). Criminal Code, ibid., ss. 249.2, 249.4(4).

Ibid., s. 249.1(3).

Ibid., ss. 79, 80. See supra note 108 and accompanying text.

Criminal Code, ibid., ss. 242, 247.

The Honourable Mr. Justice David Watt \& The Honourable Madam Justice Michelle Fuerst, The 2009 Annotated Tremeer's Criminal Code (Toronto: Carswell, 2008) at 586.

Criminal Code, supra note 6, s. 22.1. See Todd Archibald, Kenneth Jull \& Kent Roach, “The Changed Face of Corporate Criminal Liability” (2004) 48 Crim. L.Q. 367.

R. v. Jackson, [1993] 4 S.C.R. 573 at 583.

Stuart, Canadian Criminal Law, supra note 28 at 638. 
Finally — turning to the manslaughter aspect of the offence of being a party to manslaughter — the trial judge instructed the jurors that they must be satisfied on an objective standard that a reasonable person would realize the assault would lead to serious bodily harm (by which he said he meant bodily harm that was neither trifling nor transient)

In charging the jury on party liability to manslaughter, the trial judge had to deal with both a subjective and an objective mental element. The subjective element relates to the "party" aspect of the charge (i.e., the aiding and abetting aspect), whereas the objective element pertains to the manslaughter aspect. The trial judge made this distinction. First, he dealt with aiding and abetting and the three elements it was necessary for the jury to address in that connection (dealing with the subjective element of intention to aid or abet the kickers as the third element).... He then dealt with the manslaughter aspect of party liability to manslaughter, including the objective element of foreseeability of serious bodily injury, but not necessarily death

In my view his charge adequately instructed the jury on the complicated notion of party liability to manslaughter. ${ }^{150}$

Section 22 of the Criminal Code provides that one who counsels another to commit an offence is a party to that offence. The Supreme Court has also taken a subjective approach to this concept:

In short, the actus reus for counselling is the deliberate encouragement or active inducement of the commission of a criminal offence. And the mens rea consists in nothing less than an accompanying intent or conscious disregard of the substantial and unjustified risk inherent in the counselling: that is, it must be shown that the accused either intended that the offence counselled be committed, or knowingly counselled the commission of the offence while aware of the unjustified risk that the offence counselled was in fact likely to be committed as a result of the accused's conduct. ${ }^{151}$

Thus, an accused could be convicted of manslaughter through the operation of either ss. 21 or 22 of the Criminal Code.$^{152}$ The subjective mens rea requirement would apply to someone charged with counselling or aiding suicide pursuant to s. 241 of the Criminal Code.

The interaction between some of the defences and the crime of manslaughter also raises some interesting issues regarding the determination of the appropriate fault element. On a charge of murder, a successful defence of intoxication will negative the specific intent for

$150 \quad$ R. v. Mariani, 2007 ONCA 329, 223 O.A.C. 308 at paras. 53-55, 59, 66 [emphasis in original].

151 R. v. Hamilton, 2005 SCC 47, [2005] 2 S.C.R. 432 at para. 29 [emphasis in original]. The decision has been criticized as an attack on free speech and an unnecessary extension of the mens rea component to include both intent and recklessness: see K. Roach, "Counselling Murder and the Problems Presented by Hamilton” (2006) 51 Crim. L.Q. 265; Stuart, Canadian Criminal Law, supra note 28 at 712.

The Criminal Code, supra note 6, s. 23.1, provides that a person can be convicted of counselling or as a party even if the principal cannot be convicted of the offence. 
that offence and result in a conviction for manslaughter. ${ }^{153}$ Success of the defence does not establish the requisite fault for manslaughter; the Crown must prove the mens rea for manslaughter beyond a reasonable doubt. ${ }^{154}$ Similarly, mental disorder insufficient to establish the defence of insanity may prevent the Crown from proving the specific intent required for murder, resulting in a conviction for manslaughter. ${ }^{155}$ The defence of provocation operates somewhat differently. ${ }^{156}$ The accused will only be entitled to the operation of the defence, and a conviction for manslaughter, where the Crown is able to establish the specific intent required for murder. ${ }^{157}$ At that point, provocation operates as an excuse, the effect of which is to reduce murder to manslaughter. ${ }^{158}$ At one time Canadian courts recognized a common law defence of excessive force in self-defence or defence of property, allowing an intentional killing to be reduced to manslaughter. The Supreme Court of Canada has made it clear that this defence no longer exists. ${ }^{159}$

\section{CONCLUSION}

In Beatty and J.F. the Supreme Court of Canada has taken a major step forward by clarifying several of the issues that have plagued the law of manslaughter in recent years. In particular, the Court has:

1. Recognized the problem of redundancy in regard to the many manslaughter provisions found in the Criminal Code;

2. Established a clear separation between the actus reus and mens rea of manslaughter; and

3. Established three distinct categories of objective fault.

Perhaps most significantly, these decisions once again demonstrate the need to engage in comprehensive reform of Canadian criminal law. There is no shortage of excellent proposals. Studies by the Law Reform Commission and the more recent Criminal Reports Forum are

See R. v. Daley, 2007 SCC 53, [2007] 3 S.C.R. 523. See also Stuart, Canadian Criminal Law, supra note 28 at 430-49. For a recent example of intoxication reducing murder to manslaughter see $R$. $v$. Medwid, [2009] O.J. No. 1992 (Sup. Ct. J.) (QL).

See R. v. Allen, 2007 ONCA 790, 75 W.C.B. (2d) 730. On a charge of murder, a conviction for manslaughter does not require the accused to provide "affirmative evidence of an absence of intention": R. v. Culham, 2007 ONCA 775, 75 W.C.B. (2d) 728 at para. 3.

For a recent case supporting this proposition see R. v. Gomez, 2007 ONCA 696, 74 W.C.B. (2d) 846. See also Stuart, Canadian Criminal Law, supra note 28 at 414-17.

Criminal Code, supra note 6, s. 232. "Intoxication is relevant to the issue of whether the appellant had the required intent. Provocation by definition presupposes the required intent but reduces the offence to one of manslaughter" (R. v. Azzam, 2008 ONCA 467, 91 O.R. (3d) 335 at para. 66). It is not unusual to see an accused advance both defences, intoxication and provocation, in response to a charge of murder: see R. v. Sheehan, 2008 NBQB 234, 332 N.B.R. (2d) 264.

"For the jury to have found provocation as a basis for reducing murder to manslaughter the jury would necessarily have to have found that Clifford Kokopenace had formed the intent necessary for second degree murder but that he was provoked into a loss of control because of a wrongful act or insult directed at him”: R. v. Kokopenace, [2008] O.J. No. 4582 (Sup. Ct. J.) (QL) at para. 9.

R. v. Parent, 2001 SCC 30, [2001] 1 S.C.R. 761. Recent examples showing the operation of the defence of provocation include R. v. Li, 2007 ONCA 136, 221 O.A.C. 179; R. v. Hermiz (2007), 73 W.C.B. (2d) 698 (Ont. Sup. Ct. J.); R. v. Forde (2007), 75 W.C.B. (2d) 554 (Ont. Sup. Ct. J.); R. v. Gill, 2009 ONCA 124, 246 O.A.C. 390

See R. v. Faid, [1983] 1 S.C.R. 265; R. v. Gee, [1982] 2 S.C.R. 286. 
well-known examples. ${ }^{160}$ We should strive to make our criminal law clear, concise, and accessible. ${ }^{161}$ Despite the recent best efforts of the Supreme Court of Canada, the law of manslaughter continues to present a glaring example of an offence headed in the opposite direction.

160 Law Reform Commission of Canada, Recodifying Criminal Law (Ottawa: Law Reform Commission of Canada, 1987); Stuart, Delisle \& Manson, supra note 46.

161 See Stuart, Canadian Criminal Law, supra note 28 at 20-36. 
this page is blank - do not strip in 